ISSN: 2238-8052

\title{
A CIDADE E 0 CIDADÃO. VERIFICAÇÃO E ANÁLISE DO NÍVEL DE CONHECIMENTO DAS PESSOAS QUANTO À LEGISLAÇÃO URBANÍSTICA MUNICIPAL VERSUS A REALIDADE URBANA EM GARANHUNS/PE
}

\author{
THE CITY AND THE CITIZEN. \\ VERIFICATION AND ANALYSIS OF THE LEVEL OF KNOWLEDGE OF PEOPLE REGARDING URBAN \\ LEGISLATION, IN GARANHUNS/PE
}

Maria do Carmo de Albuquerque BRAGA ${ }^{1}$

Palavras-chave: Discrepâncias; Participação popular; Legislação urbanística; Planejamento; Gestão Urbana.

Keywords: Discrepancies; Popular participation, Urban planning legislation; Planning, Urban management.

\section{R E S U M O}

Observando a cidade, percebem-se discrepâncias entre a legislação urbana e a realidade, pois o cidadão a desconhece, logo, a descumpre. Esse fato talvez possa ser explicado pelo pouco interesse das pessoas acerca dessas leis, além do desinteresse dos gestores públicos em promovê-las. Assim, o trabalho objetivou verificar o nível de conhecimento das pessoas quanto à legislação urbana existente em confronto com a realidade vivida, em Garanhuns/PE, auxiliando o poder público a aperfeiçoar a participação popular no processo de planejamento e gestão urbanos, de forma melhorar a qualidade do ambiente. Para tanto, foram selecionados quatro dos doze bairros para aplicação de questionário dirigido à população local, com base nas maiores e menores discrepâncias na oferta de amenidades entre eles. Os resultados confirmaram que a legislação ainda se encontra distante da realidade e que as pessoas terminam por perder a noção do que seja ideal, acostumando-se com o que lhes é o ofertado.

\begin{abstract}
A B S T R A C T
By looking at the city one can find discrepancies between urban legislation and the local reality because citizens are unaware of and, therefore, do not comply with such laws. This may explain people's lack of interest in these laws as well as their application by authorities. Thus, the objective of this study has been to verify the level of knowledge of people regarding the existing legislation, helping the Government Administration to increase popular participation in urban planning and administration in order to improve the quality of environment. Thus, four in the twelve neighborhoods of the city were selected for the application of a questionnaire addressed to the residents based on discrepancies in existing amenities. The results confirmed that complying with the legislation is still far from the process of constructing the city. Besides, it seems that people end up accepting what they are given instead of fighting for what is best to them.
\end{abstract}

\footnotetext{
1 Professora Adjunta da Universidade Federal Rural de Pernambuco, Unidade Acadêmica de Garanhuns, doutora em Desenvolvimento Urbano. mariabraga77@gmail.com.
} 


\section{INTRODUÇÃO}

Observando a cidade, é possível perceber elementos que caracterizam o espaço no qual se está inserido, como ruas, quadras, bairros, praças, escolas, postos de saúde e tantos outros. Porém, a sociedade que conforma e é conformada por esses espaços, por vezes, não conhece os aspectos legais que devem reger a organização dos mesmos, perde a noção do que seja o ideal para costumar-se com o que lhe é ofertado, tornando-se corresponsável por inadequações.

As discrepâncias existentes entre a legislação e o cotidiano das cidades são bem perceptíveis, o que pode ser explicado através do pouco conhecimento e interesse por parte do cidadão acerca dessas leis, além do não cumprimento do dever por parte dos gestores públicos em promovê-las. Juntamente a esse fato, pode-se observar que a escrita dos códigos legislativos se encontra distante do contexto da sociedade. Textos ornados e termos muito complexos dificultam a clareza e entendimento de pessoas leigas, desmotivando também a busca desse conhecimento. 0 jogo político adentra nesse campo como um aspecto forte para o 'esquecimento e engavetamento' das leis acerca da construção cotidiana da cidade.

Para saber como agir diante de algumas situações existentes na cidade foi criado em 2001 a Lei Federal no 10.257, o Estatuto da Cidade, que estabelece normas "de ordem pública e interesse local" (BRASIL, 2002), com a finalidade de disciplinar o uso das propriedades urbanas com vistas ao benefício coletivo, além da proteção do meio-ambiente. Em suma, o Estatuto objetiva orientar o crescimento da cidade por meio de diretrizes estabelecidas e por um conjunto de instrumentos legais para viabilizá-las. 0 propósito é fazer com que os municípios as cumpram, tendo como base a realidade local e a participação do cidadão no processo, uma vez que a finalidade é atingir o bem comum.

Como estabelece o Estatuto da Cidade, o Plano Diretor é o principal instrumento legal ao lado da Lei Orgânica em um município e se caracteriza como um conjunto de estratégias e instrumentos voltados para sua organização e seu desenvolvimento, como os usos dos espaços urbanos, as redes de infraestrutura e outras questões fundamentais na estrutura urbana. Todos os elementos que envolvem o Plano Diretor Municipal precisam ser discutidos de forma democrática entre a sociedade e poder público. Esse documento deve ser viabilizado por leis complementares que auxiliam os gestores públicos a tomarem decisões sensatas quanto ao desenvolvimento local. Mas, muitas vezes, se observa que uma parcela do município não possui as mínimas condições de infraestrutura, avolumando a desorganização e riscos que realçam as desigualdades sociais, espaciais e econômicas existentes.

o conhecimento das leis que disciplinam o desenvolvimento urbano do país auxilia na compreensão de que é possível construir uma cidade justa, na qual os cidadãos conheçam seus direitos e deveres. Observa-se, portanto, que o desejo de construir uma cidade em que haja a participação da 
sociedade é entendido como uma meta possível, juntamente com a efetivação das leis por parte do governo.

Assim, o objetivo desse trabalho foi o de verificar o nível de conhecimento das pessoas quanto à legislação urbanística municipal em confronto com a realidade vivida, em Garanhuns/PE. A intenção é a de auxiliar o poder público a aperfeiçoar a participação popular no processo de planejamento e gestão urbanos, de forma a melhorar a qualidade dos ambientes que conformam a cidade, além de resgatar a noção do que seja o ambiente ideal para a vida cotidiana. Para tanto, foram definidas metas: (1) Analisar relações sociais, políticas, econômicas e culturais presentes na construção da cidade; (2) Relacionar conhecimento científico e sua colaboração na explicação da realidade local; (3) Utilizar os conceitos adquiridos na escola para compreender a produção do espaço da cidade e do espaço local; e, por fim, (4) Desenvolver o espírito cooperativo na construção de um ambiente solidário, com maior justiça social. Destaca-se que a justificativa do trabalho centra-se na evidente necessidade de transformar a cultura do cidadão de mero expectador e receptor das decisões de planejamento e gestão para coadjuvante, tal como determina a legislação urbana atual. Nesse sentido, a estrutura de trabalho contempla cinco partes. A primeira refere-se a uma breve introdução do tema; a segunda, um resgate do processo de participação social na elaboração do Plano Diretor em Garanhuns, enquanto que na segunda, analisam-se os resultados obtidos nos questionários, evidenciando o nível de conhecimento das pessoas quanto à legislação urbanística; e, na terceira, salienta-se a importância da escola enquanto forte contribuinte na formação do jovem cidadão na construção cotidiana da cidade. Assim, com os resultados obtidos conclui-se que a legislação ainda se encontra distante da realidade e que as pessoas terminam por perder a noção do que seja ideal, acostumando-se com o que é ofertado.

\section{A PARTICIPAÇÃO SOCIAL NO DESENVOLVIMENTO DO PLANO DIRETOR EM GARANHUNS}

Para viabilizar a pesquisa, tomou-se como recorte espacial o município de Garanhuns, situado na região do Agreste Meridional de Pernambuco (Figura 1), que possui uma população estimada de 137.810 habitantes, de acordo com o site do IBGE, em 2016. 0 município - composto por nove bairros, sendo eles Heliópolis, Novo Heliópolis, Dom Hélder Câmara, Dom Thiago Postma, José Mariano Dourado, Severiano Moraes Filho, Aluísio Pinto e Boa Vista - possui área territorial de $129.408 \mathrm{Km}^{2}$, com densidade demográfica de 282,21 (hab./ $\mathrm{Km}^{2}$ ) e concentração urbana de $88 \%$. 
Figura 1. Localização do município de Garanhuns/PE, local de desenvolvimento da presente pesquisa.

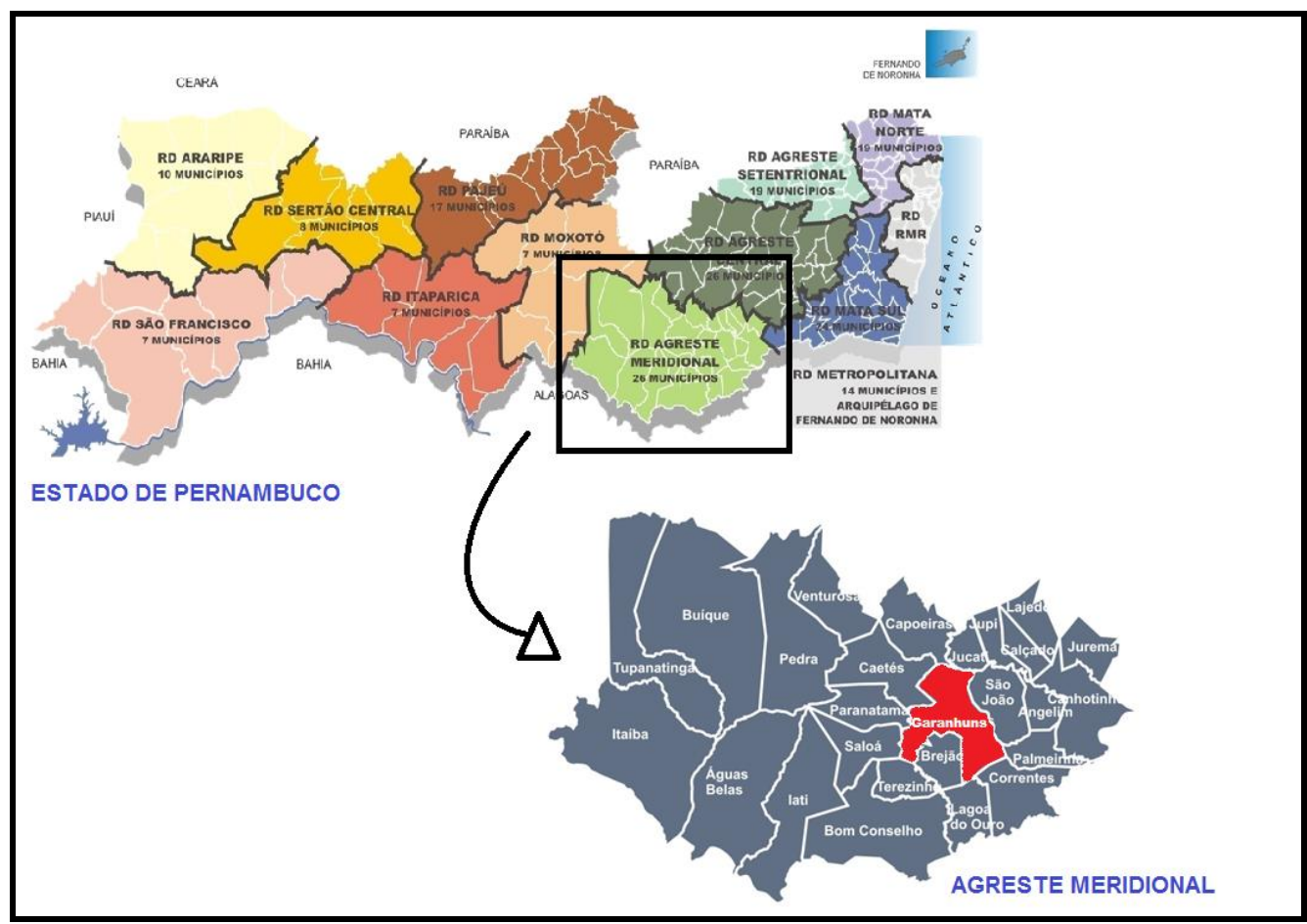

Fonte: Agência Condepe/Fidem (2010), modificado pela autora.

Inicialmente, para melhor se compreender a legislação que rege o ordenamento do espaço em Garanhuns/PE, foram necessárias visitas à Secretaria de Planejamento do município para consultar a legislação urbanística e os parâmetros urbanísticos adotados. 0 Plano Diretor Municipal de 2008, que ainda se encontra em vigor, foi apresentado, embora se encontre disponível no site da prefeitura, visto ser uma das exigências do Estatuto da Cidade, para os municípios com 20.000 habitantes ou mais (OLIVEIRA, 2001).

A Lei Federal No. 10.257 - Estatuto da Cidade -, promulgada em julho de 2001, entrou em vigor em outubro do mesmo ano. Foi criada para regulamentar os artigos 182 e 183 da Constituição Federal de 1988, referentes à Política Urbana, oriunda dos movimentos de Reforma Urbana ocorridos nos anos 1960 (BRASIL, 2002, p. 21).

O Estatuto oferece instrumentos urbanísticos que viabilizam o desenvolvimento urbano. Não obstante, cada município, de forma democrática, define em seus Planos Diretores quais instrumentos poderão ser utilizados e como serão suas aplicações. Nesse sentido, o ex-ministro das cidades, Márcio Fortes, expõe que a partir dessa nova ordem legal sobre a participação popular no processo "a democracia muda de qualidade quando o Poder Público se une à experiência acumulada da sociedade organizada e potencializa a sua participação na elaboração e execução dos programas e das políticas públicas" (In GRAZIA, 2006, n.p.). Ao atender essa nova exigência legal, Cymbalista (1999, p.2) chama a atenção que "a regulação urbanística e seus instrumentos - o Plano Diretor, a Lei de Uso e Ocupação do Solo, a Lei de Parcelamento - muitas vezes são omissos, apresentam problemas de interpretação ou são inadequados em relação a novos usos que vão surgindo com o passar do tempo. Estas leis e 
normas são, na verdade, um instrumental que requer uma política que as implemente e faça a sua gestão." Para tanto, a participação social no processo evidencia-se como fundamental.

O atual Plano Diretor de Garanhuns transformou-se em Lei No. 3620/2008, que foi sancionada pelo então prefeito, em dezembro do mesmo ano (GARANHUNS, 2008). Grupos representativos de diversas partes do município, em conjunto com uma equipe técnica local, participaram de sua construção, de acordo como os requisitos legais.

Assim, ao longo do presente trabalho, foram estudadas algumas leis complementares ao Plano Diretor Municipal como Zoneamento Urbano, Perímetro Urbano, Uso e Ocupação do Solo Urbano, Código de Obras e Código de Posturas.

Desta forma, foi possível estudar essas leis e poder verificar o nível de conhecimento das pessoas quanto as suas aplicações no cotidiano. É importante destacar que o que se busca neste trabalho é o nível de conhecimento e não de entendimento acerca da legislação, visto que, neste caso, conhecer pressupõe apenas saber da existência de algo enquanto entender, ter a noção do seu significado, seja de forma superficial ou aprofundada.

Assim, com o conhecimento legal e a leitura do Plano Diretor Municipal (2008), tornou-se possível definir então recortes espaciais que viabilizassem o trabalho, selecionando quais partes da cidade seriam estudadas, partindo de critérios como bairros que possuíssem grandes diferenças na oferta de infraestrutura, por exemplo. Dessa forma, os bairros selecionados foram analisados em sua totalidade, sendo eles: Heliópolis, Novo Heliópolis, Aluísio Pinto e Boa Vista, conforme pode ser visto na figura 2.

Figura 1: Sede municipal de Garanhuns e a estrutura dos bairros selecionados.

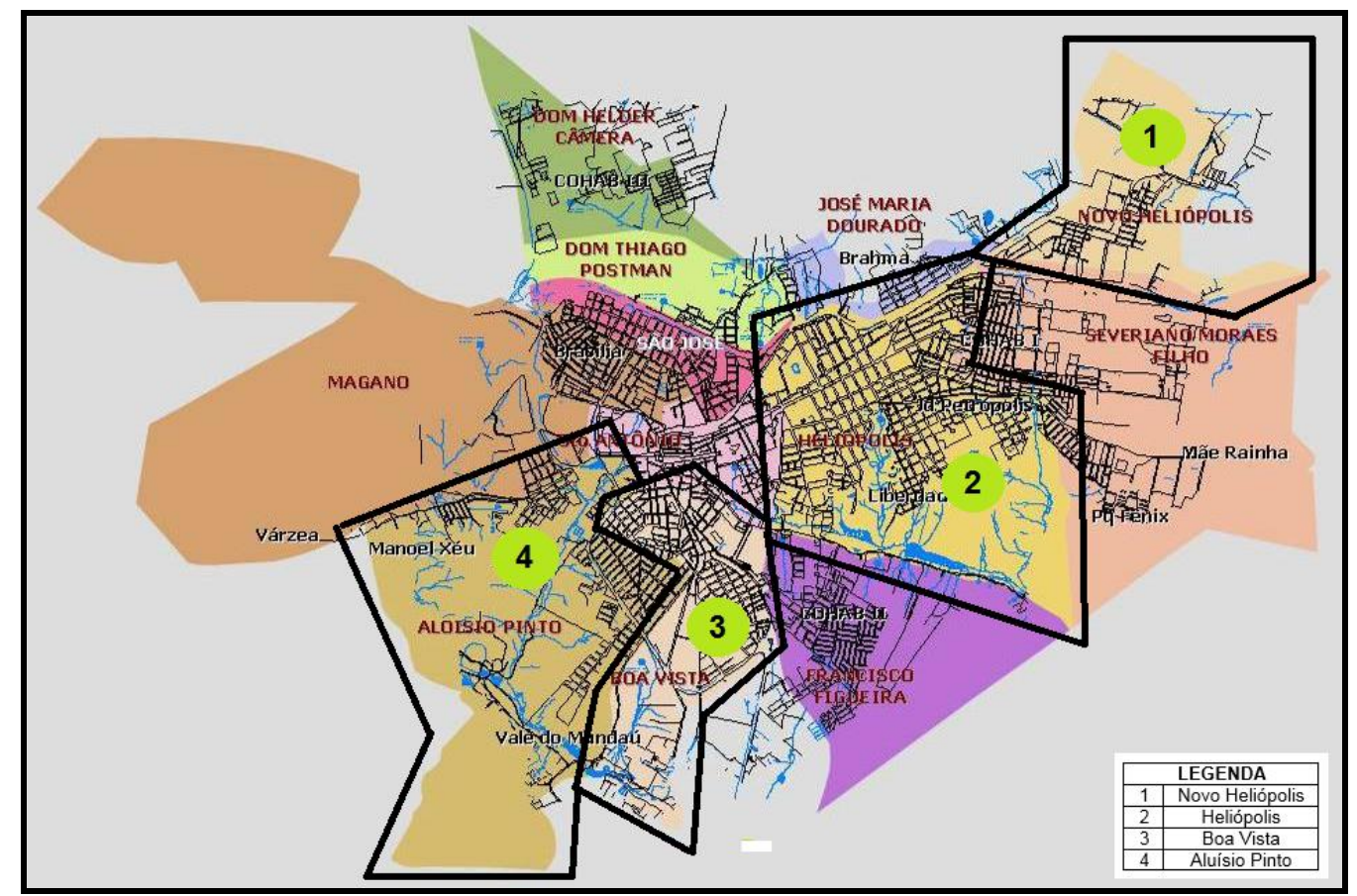

Fonte: Plano Diretor de Garanhuns (2008), modificado pela autora. 
As discrepâncias observadas entre os quatro bairros selecionados (Quadro 1) se expressaram em alguns aspectos que auxiliaram na construção do questionário a ser utilizado na pesquisa, segundo os objetivos estabelecidos. O questionário foi dividido em duas partes: a primeira foi construída, objetivando identificar se os entrevistados, pelo menos, sabiam ou não da existência da legislação urbanística local, incluindo o Plano Diretor, e a segunda, o nível de satisfação do entrevistado sobre o lugar onde mora e participa cotidianamente. Para ficarem mais claras as questões e facilitar o entendimento dos cidadãos sobre o que estava sendo perguntado, foi construído um resumo sobre o que significava cada uma das leis, possibilitando melhor resposta e resultado. Os elementos da segunda parte do questionário se basearam em aspectos necessários para uma melhor qualidade de vida do cidadão.

Quadro 1: Divergências entre os bairros, relatadas pelo Plano Diretor de Garanhuns/PE.

\begin{tabular}{|c|c|}
\hline BAIRROS & DIVERGÊNCIA \\
\hline Heliópolis & \multirow{2}{*}{$\begin{array}{ll}\text { - } & \text { Baixa densidade de ocupação; } \\
\text { - } & \text { Edificações recuadas nos lotes; } \\
\text { - } & \text { Lotes de maior densidade; } \\
\text { - } & \text { Comércio e Serviços de lazer. }\end{array}$} \\
\hline Aluísio Pinto & \\
\hline Novo Heliópolis & \multirow{2}{*}{$\begin{array}{l}\text { - Ocupação lindeira ao lote ou com } \\
\text { pequenos recuos; } \\
\text { - } \quad \text { Casas geminadas; } \\
\text { - Densidade de ocupação elevada. }\end{array}$} \\
\hline Boa Vista & \\
\hline
\end{tabular}

Fonte: Plano Diretor de Garanhuns/PE (2008), modificado pela autora.

Sendo a participação dos cidadãos nas decisões de gestão que envolve o interesse público garantida pela Constituição Federal, por diversas formas como iniciativa popular, consultas, audiências públicas e conselhos de gestão de políticas ou serviços públicos, o Estatuto da Cidade estabeleceu a obrigatoriedade de uma representatividade social, e não apenas política, dos diversos setores como associações de bairro, comércio, indústria, etc.

Verificou-se, com isso que para a construção do Plano Diretor de Garanhuns, em 2008, o Núcleo Municipal de Acompanhamento do processo participativo identificou quatro grupos representativos, sendo estes: grupo 1 - Comércio, Serviço, Indústria e Produção Agrícola; grupo 2 Saúde e Educação; grupo 3 - Moradia e Ambiente Urbano (Patrimônio Cultural e Natural); e grupo 4 Pequena Produção Rural e Meio Ambiente, totalizando dezessete (17) representantes no processo, contribuindo nas etapas de leitura comunitária, tomada de decisões e construção do documento final para aprovação em audiência pública.

A partir desse conhecimento e em função do tempo decorrido entre a construção do Plano Diretor de Garanhuns e o desenvolvimento da presente pesquisa, observou-se não ser mais possível contar com o apoio dos mesmos participantes da época. Por esta razão, e enfrentando as persistentes dificuldades na participação do cidadão em um processo como este, buscou-se minimamente aplicar o BRAGA, M. C. A. A cidade e o cidadão. Verificação e análise do nível de conhecimento das pessoas quanto à legislação... 
questionário contando com o mesmo número de pessoas que participaram na época da construção do mencionado Plano, especialmente de representantes sociais e de cidadãos comuns, em cada um dos quatro bairros selecionados, pois como afirma Gadotti (2006, p.139) "como sujeitos da Cidade, necessitamos nos sentir cidadãos", já que Conselho Municipal de Políticas Urbanas, oriundo do Núcleo Municipal de Acompanhamento da construção do Plano de 2008, se encontrava inativo há cerca de três anos.

Nesse sentido, verifica-se ainda que, embora esta pesquisa seja de cunho quantitativo, o aspecto qualitativo dele decorrente é bem significativo para os propósitos do trabalho, logo, o número amostral não se torna relevante visto que o percentual adotado para tal é igual ou maior ao percentual adotado no desenvolvimento do Plano Diretor, em 2008.

Quanto às técnicas, foram utilizadas: a observação simples, com o intuito de verificar a realidade presente em cada um dos bairros selecionados em confronto com o que foi respondido pelo entrevistado e o que estabelece a legislação urbanística para o local.

Para além desse entendimento, na tabela 1, pode-se perceber a relação entre o número de habitantes para o município de Garanhuns, em 2008, e o número de representantes escolhidos para a construção do Plano Diretor de Garanhuns nesse mesmo ano. A seguir, o número de habitantes do município em 2017 e o mesmo número de representantes, com seu respectivo percentual. Além desses, observam-se ainda o número de habitantes em cada um dos quatro bairros escolhidos para a pesquisa e o número de entrevistados em cada um destes, seguidos de seus respectivos percentuais.

Tabela 1: Relação do número de habitantes e do número de entrevistados.

\begin{tabular}{l|c|c|c}
\hline \multicolumn{1}{c|}{ Local } & Total de habitantes (aprox.) & Representantes & Percentual (\%) \\
\hline Garanhuns (2008) & 117.219 & 17 & 0,015 \\
\hline Garanhuns (2017) & 137.810 & 17 & 0,012 \\
\hline \multicolumn{2}{|c|}{ Dados relativos aos percentuais atuais por bairro } \\
\hline Aluísio Pinto & 11.893 & 23 & 0,19 \\
\hline Novo Heliópolis & 2.201 & 19 & 0,86 \\
\hline Boa Vista & 10.722 & 17 & 0,16 \\
\hline Heliópolis & 19.409 & 17 & 0,09 \\
\hline
\end{tabular}

Fonte: CENSO - IBGE, 2000 e 2010 in IBGE (2017)

A relação é feita considerando os dados computados para a população existente no município em 2008 e os dados populacionais relativos ao ano de 2017. Como expresso no Plano Diretor: "De acordo com o Censo IBGE/2000, a população do Município de Garanhuns é de 117.219 habitantes. Deste total, 103.435 são habitantes da área urbana e 14.314 da área rural. A densidade demográfica de $251,4 \mathrm{hab} / \mathrm{km}^{2} . "$

Assim, considerando os dados percentuais para 2008 e os dados percentuais para 2017, foi possível entender e verificar o número da amostra de entrevistados para cada um dos bairros 
adotados na pesquisa, pois a soma dos percentuais apresenta-se maior que o percentual adotado para o município como um todo, em 2008, o que autoriza sua validação.

Para a aplicação do questionário, foram formuladas perguntas quanto à legislação local e perguntas referentes ao que oferece cada bairro. Nessa etapa da pesquisa, o objetivo era o de realizar levantamento de dados e informações dos seguintes aspectos: o conhecimento por parte dos cidadãos quanto à legislação local; o nível de satisfação dos cidadãos quanto à oferta de infraestrutura ligada aos serviços de saneamento básico, abastecimento de água, posto de saúde, escolas, coleta de lixo, iluminação pública; qualidade das vias de acesso ao transporte coletivo; tipo de transporte coletivo e seus trajetos; localização dos tipos de comércio, dos serviços (públicos e privados) e da feira; praças e espaços destinados a atividades esportivas; grupos culturais, artísticos e clubes de lazer; localização dos templos religiosos; localização e funcionamento de associações e conselhos de moradores; áreas verdes e áreas de degradação ambiental; segurança e qualidade de vida.

Foram estabelecidos locais para a realização da entrevista, em dias e horários diferentes. Do dia oito aos vinte e um de janeiro de dois mil e dezessete, foram utilizados três dias úteis durante a semana para a aplicação do questionário. Para privilegiar cidadãos que, por diversos motivos, não se encontravam em seus bairros durante os dias úteis, foram utilizados finais de semana. Porém, como Garanhuns é polo comercial para os municípios circunvizinhos e durante os finais de semana o número de pessoas de diferentes municípios eleva-se, foram priorizados dias úteis como forma de garantir a participação do cidadão, além de representantes sociais e dos diversos setores como associações de bairro, possibilitando um retrato mais fiel do conhecimento do cidadão local.

\section{O NÍVEL DE CONHECIMENTO DO CIDADÃo QUANTO A LEGISLAÇÃo URBANíSTICA EM GARANHUNS}

Sabe-se da importância da participação da sociedade na construção de uma cidade justa, na qual os cidadãos afirmam que - além de conhecer - precisam compreender, participar, acompanhar e cobrar a efetivação das leis urbanísticas, como estabelece o Estatuto da Cidade. Neste sentido, entende-se que o ato de conhecer seja apenas saber da existência de algo, mas saber que algo existe não implica em que haja, por parte da população, uma compreensão maior, que exige uma profundidade no assunto, mas que se reconhece que existe e se possui um conhecimento superficial apenas e não o entendimento. Assim, surgiram as primeiras conclusões quanto à pesquisa em seu início, com os resultados do levantamento sobre o nível de conhecimento do cidadão acerca da legislação urbanística local.

As leis urbanísticas têm por objetivo ordenar o funcionamento do espaço urbano, sendo de suma importância para o bom relacionamento entre as pessoas. De certa forma, é essencial todos conhecerem o ordenamento jurídico que se impõe sobre a cidade, e esse fato ficou claro nesta fase da pesquisa. É possível observar o distanciamento de uma parte da população quanto à legislação local e 
como isso se reflete nos bairros onde moram esses cidadãos. 0 gráfico 1 permite entender melhor essa afirmação, tendo como referência o conhecimento das pessoas acerca do Plano Diretor do município em vigor.

Os dados obtidos no gráfico mostram que nos dois primeiros bairros, Heliópolis e Aluísio Pinto, a quantidade de pessoas que conhecem o Plano Diretor é bem maior que nos dois últimos bairros, Novo Heliópolis e Boa Vista. Isso pode ser explicado pelo nível social baixo de seus residentes e, por conseguinte, uma participação muito baixa na construção do lugar. Ademais, observou-se que os dados obtidos se referem aos cidadãos residentes nos bairros que mais apresentam problemas quanto à infraestrutura e organização espacial.

Gráfico 1: Respostas dos moradores dos bairros selecionados quanto ao conhecimento do Plano Diretor de Garanhuns/PE.

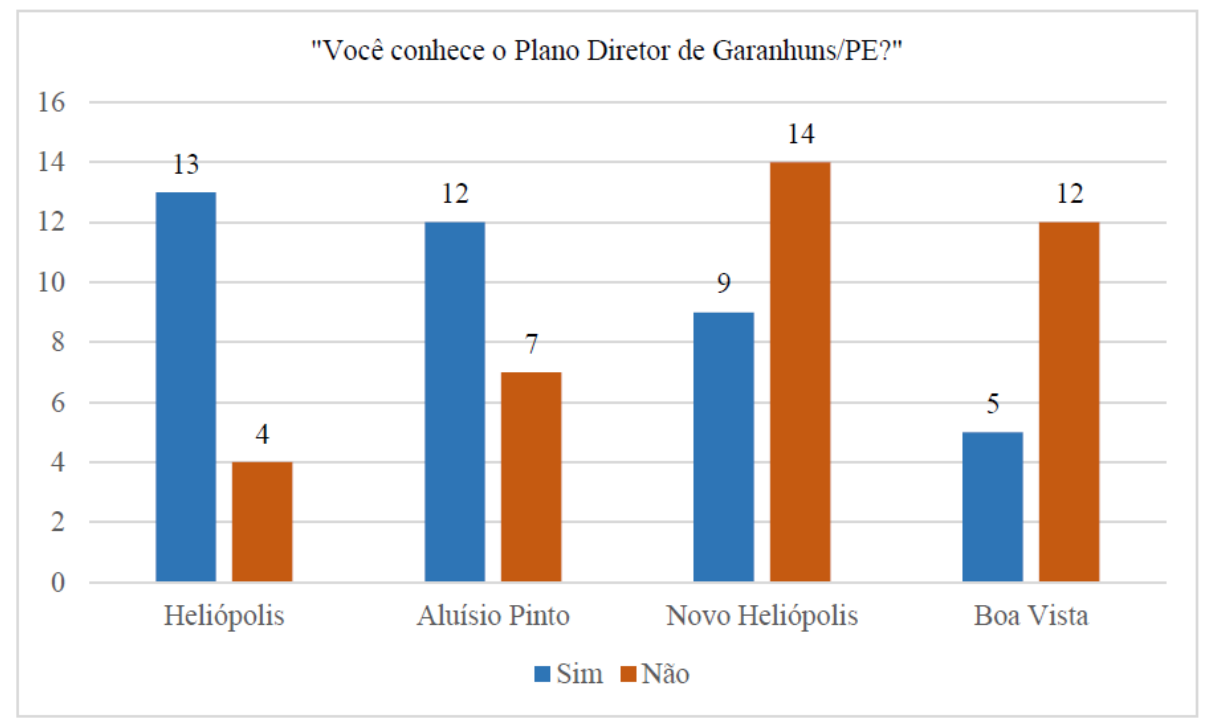

Fonte: Autora (2017).

Quanto ao gráfico 2, conhecimento dos entrevistados sobre a Lei do Perímetro Urbano, observa-se que nos bairros que dispõem de certa organização espacial, há um maior entendimento quanto a lei em questão. Como esta lei auxilia o município a, de fato, direcionar as políticas públicas para cada zona, urbana e rural, deduz-se que os moradores desses bairros conhecem o significado de zona urbana e o de zona rural e, mais que isso, sabem o que pode ser reivindicado para cada um. 
Gráfico 2: Respostas dos moradores dos bairros selecionados quanto ao conhecimento da Lei do Perímetro Urbano em Garanhuns/PE.

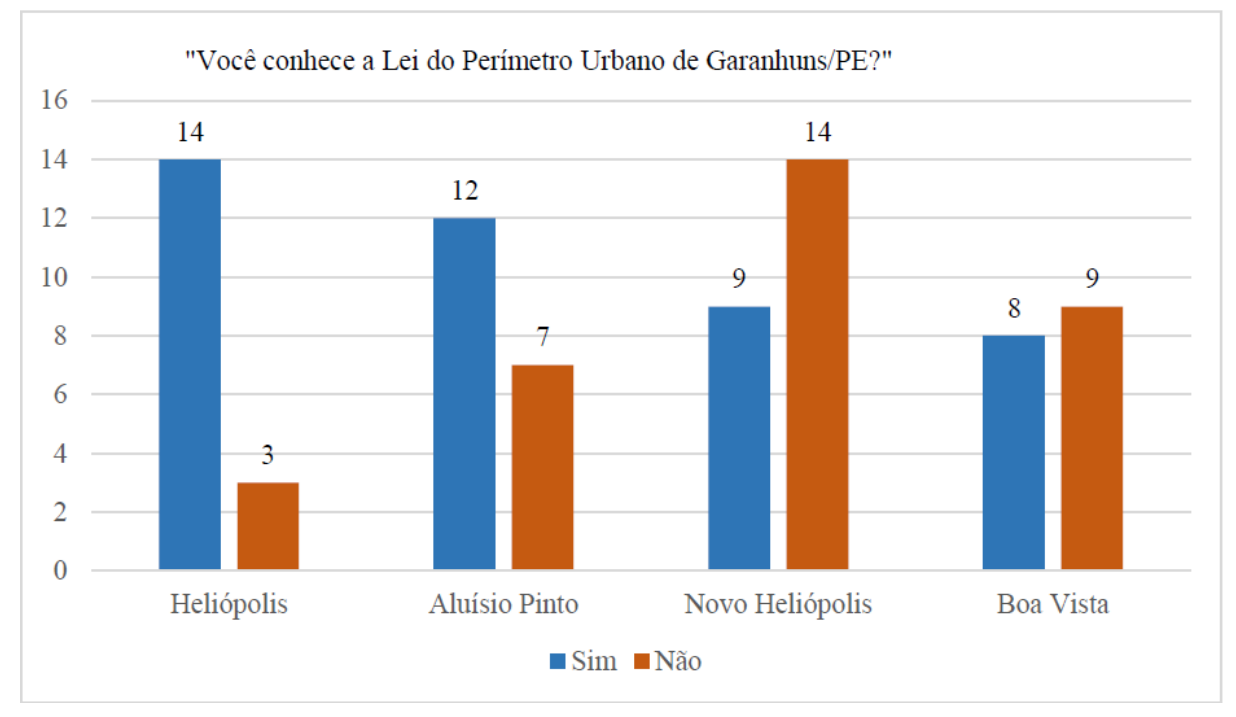

Fonte: Autora (2017).

Com relação à Lei de Uso e Ocupação do Solo Urbano (Gráfico 3), percebe-se que o número de entrevistados que não a conhecem é baixo, nos bairros habitados por cidadãos de condição financeira e social média à alta, diferentemente do que se apresenta nos bairros habitados por cidadãos de condição menos favorecida, cujo percentual representa quase o dobro daquele, e isso dificulta ainda mais a organização do lugar, já que esta lei estabelece critérios e parâmetros de como usar e ocupar o espaço urbano, de forma a melhorar a qualidade de vida da população.

Gráfico 3: Respostas dos moradores dos bairros selecionados quanto ao conhecimento da Lei de Uso e Ocupação do Solo Urbano em Garanhuns/PE.

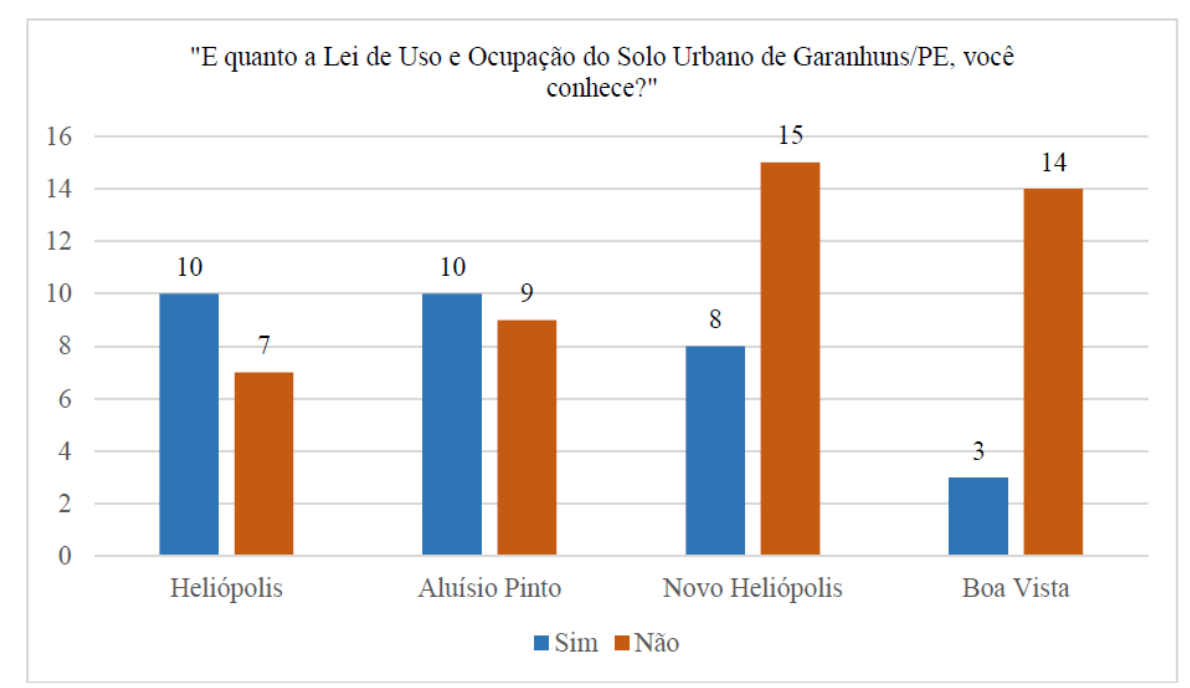

Fonte: Autora (2017) 
Durante as entrevistas, muitos dos moradores relataram a sua falta de conhecimento quanto ao Código de Obras, o que também era percebido nas construções existentes em alguns pontos dos bairros. Tais construções foram feitas segundo o entendimento de cada um e, assim, não cumprem as exigências contidas no Código. Pode-se melhor entender a questão visualizando o gráfico 4, no qual se observa que os resultados não são tão satisfatórios em três dos bairros estudados. Além de garantir conforto, segurança, preservação ambiental e outros, o Código de Obras auxilia na apresentação da arquitetura nos bairros.

Gráfico 4: Respostas dos moradores dos bairros selecionados quanto ao conhecimento do Código de Obras em Garanhuns/PE.

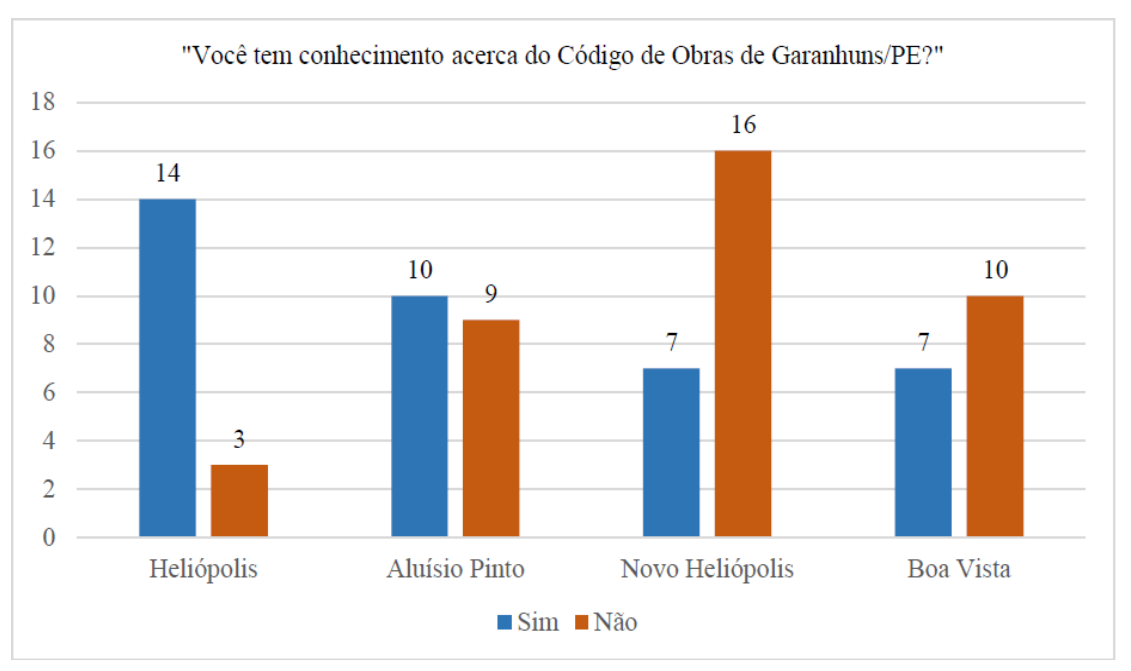

Fonte: Autora (2017).

Com relação ao Código de Postura, observa-se no gráfico 5 que há um entendimento maior nos bairros onde residem os cidadãos de condição financeira e social melhor, evidenciando um melhor convívio entre esses moradores. Durante as entrevistas encontrou-se nos entornos de algumas ruas dos bairros onde residem os cidadãos de menor poder aquisitivo, metralhas, lixo em cima das calçadas o que dificultava a passagem dos pedestres e, até mesmo animais de grande porte, como burros e cavalos, amarrados em postes o que poderia vir a causar acidentes. 
Gráfico 5: Respostas dos moradores dos bairros selecionados quanto ao conhecimento do Código de Postura em Garanhuns/PE.

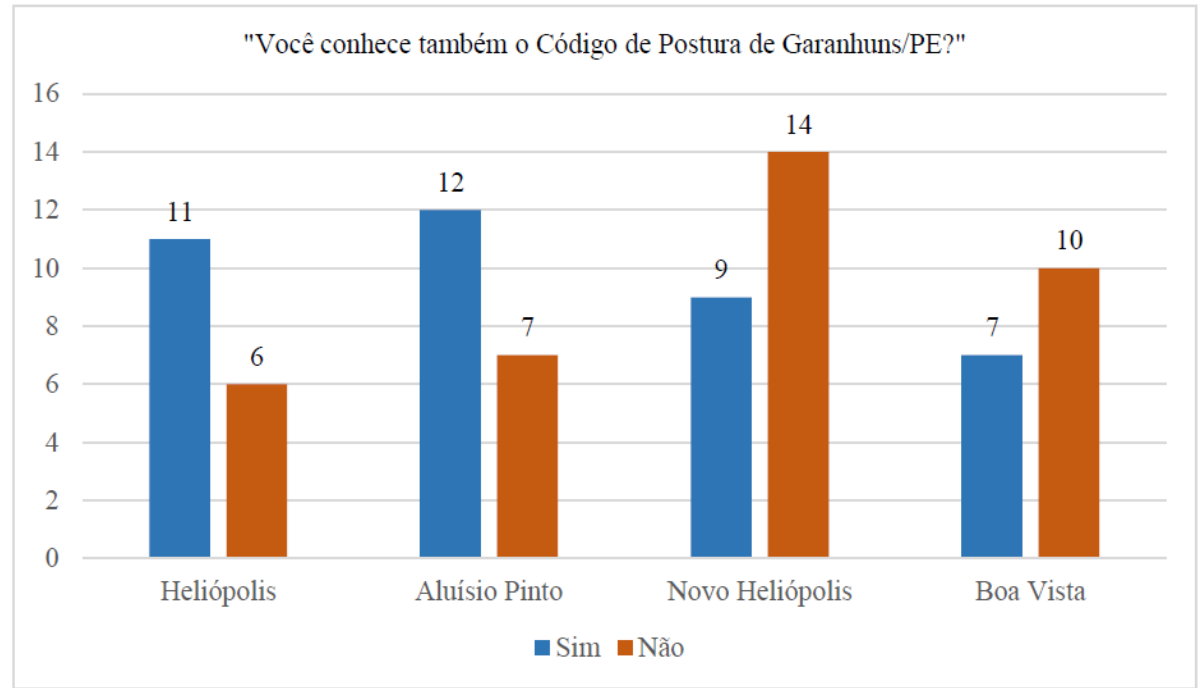

Fonte: Autora (2017).

O Zoneamento Urbano é um instrumento que é trabalhado no Plano Diretor e que divide a cidade em zonas para as quais são definidos parâmetros (usos permitidos, taxa de ocupação, número de pavimentos, entre outros). Observando o gráfico 6, verifica-se que o nível de conhecimento dos cidadãos quanto a esse aspecto é baixo, evidenciando a discrepância entre a realidade local e o que recomenda a legislação.

Gráfico 6: Respostas dos moradores dos bairros selecionados quanto ao conhecimento da Lei do Zoneamento em Garanhuns/PE.

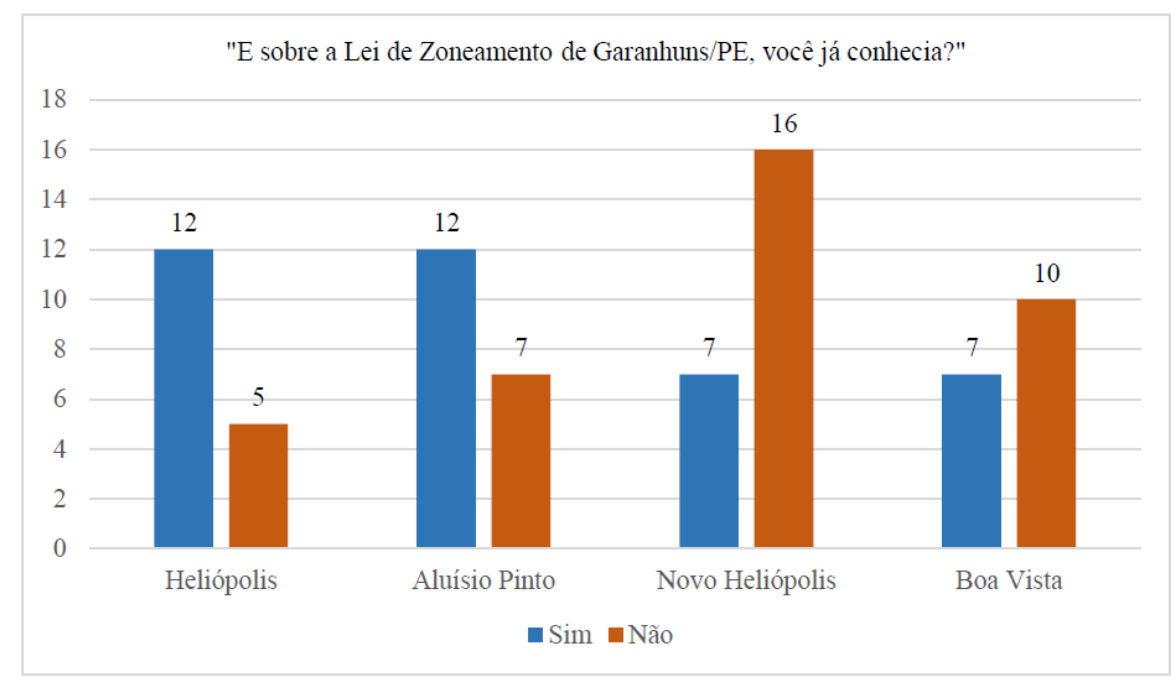

Fonte: Autora (2017).

Na segunda parte do questionário foram verificadas questões relativas ao nível de satisfação dos moradores sobre o bairro onde moram e participam da construção cotidiana, como transporte, 
comércio local, segurança e outros, tendo como resultados os dados que podem ser constatados também em gráficos.

Os gráficos 7 e 8 indicam que a maioria das pessoas estão satisfeitas, mesmo sendo o único meio de transporte disponível (lotação) em três dos quatro bairros.

Em relação aos grupos artísticos ou culturais nos bairros (Gráfico 9), observa-se que não há tanto conhecimento por parte dos moradores sobre a existência destes, apenas cinco moradores do bairro Heliópolis - o Centro Cultural Alfredo Leite Cavalcanti - e dois do Aluísio Pinto alegaram conhecer um grupo cultural, apesar de não saberem o nome do centro que se encontra no bairro Aluísio Pinto, sem evidenciar satisfação quanto ao tema.

Gráfico 7: pergunta quanto ao nível de satisfação acerca do transporte em seu bairro.

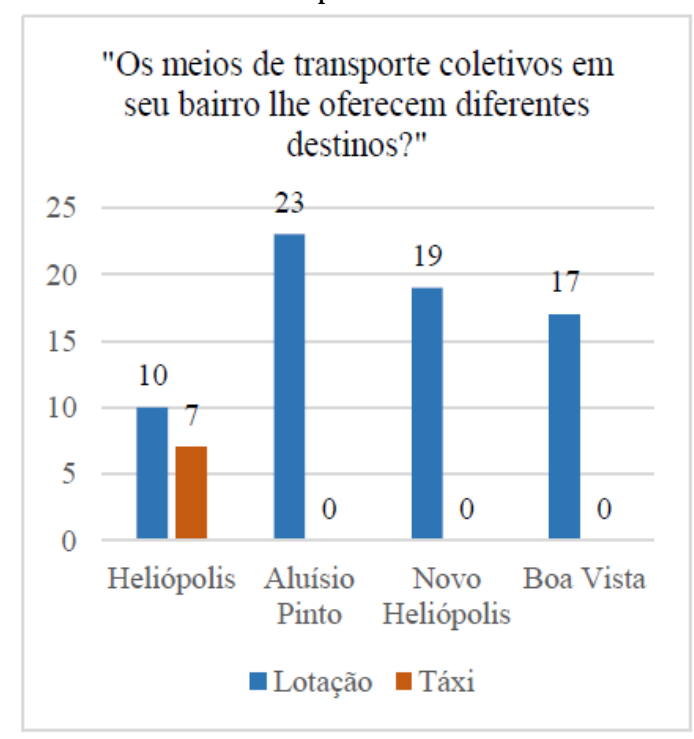

Fonte: Autora, 2017.

Gráfico 9: pergunta referente ao nível de satisfação acerca da existência de grupos culturais artísticos em seu bairro.

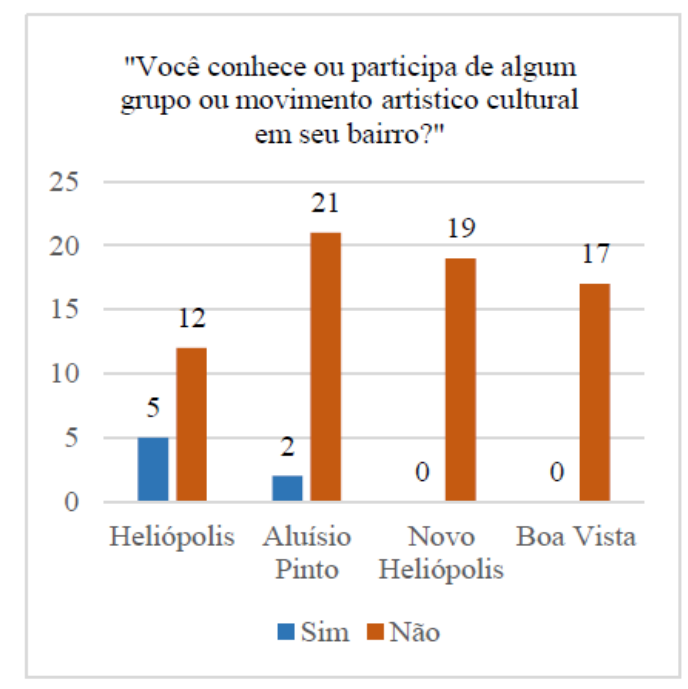

Fonte: Autora, 2017
Gráfico 8: pergunta referente ao nível de satisfação acerca da qualidade das vis e trajetos do transporte em seu bairro.

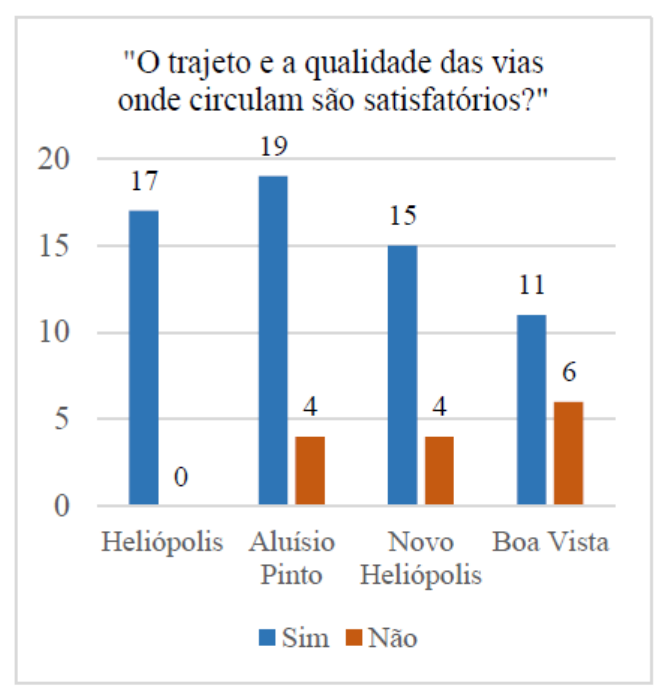

Fonte: Autora, 2017.

Gráfico 10: pergunta referente ao nível de satisfação acerca da existência de associações de moradores em seu bairro.

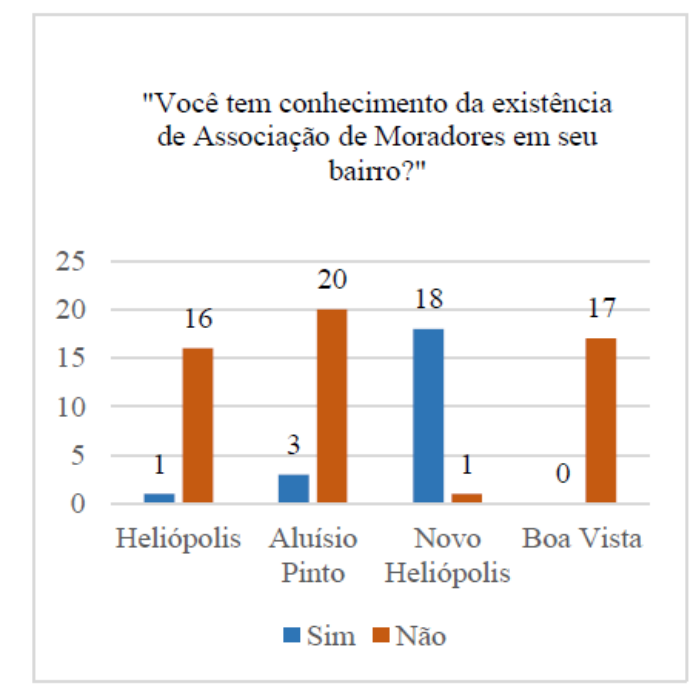

Fonte: Autora, 2017 
Os gráficos 10, 11 e 12 evidenciam que, em seus bairros, os entrevistados de Novo Heliópolis se destacam, enquanto que os dos demais bairros não sabiam responder se, de fato, existem associações, pois não há divulgação das mesmas. Alguns que responderam "sim" não sabiam a frequência das reuniões, pois não participavam, apenas um entrevistado conhecia sobre funcionamento, assuntos discutidos e reuniões.

Gráfico 11: pergunta referente à sua participação nas associações em seu bairro.

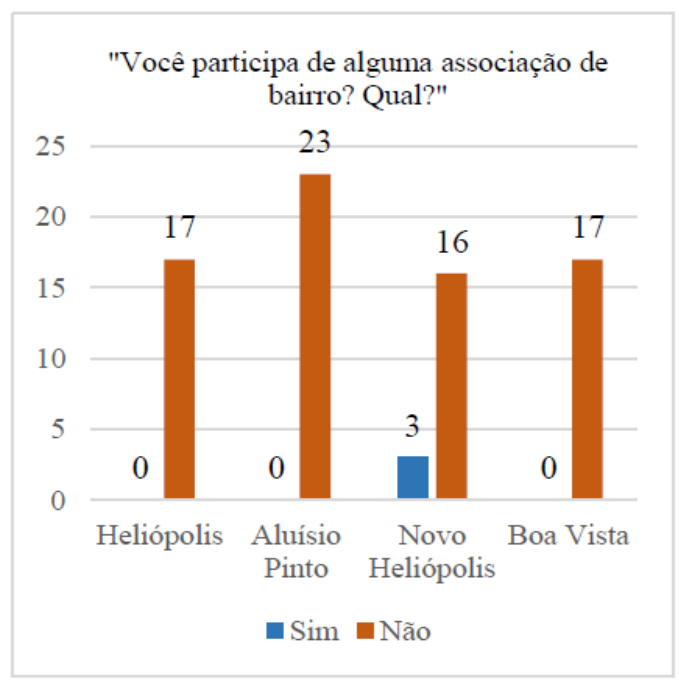

Fonte: Autora, 2017.

Gráfico 13: pergunta referente ao nível de satisfação acerca da segurança em seu bairro.

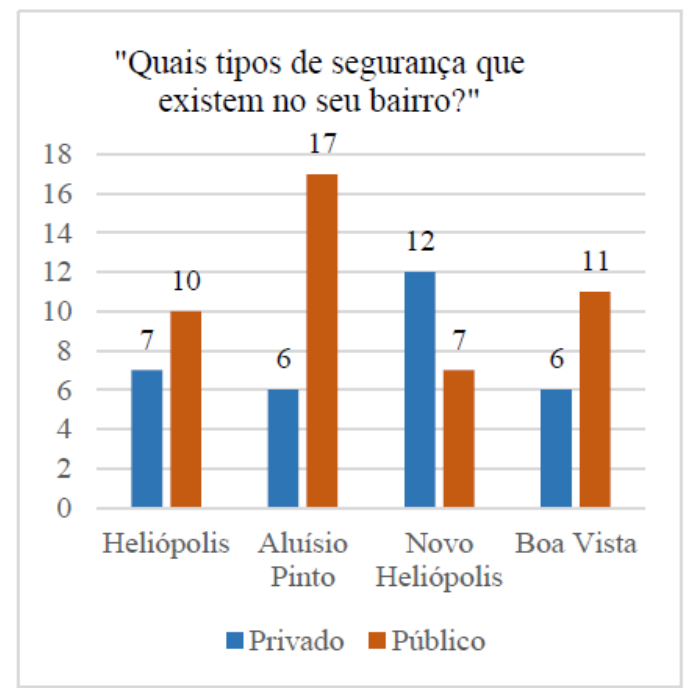

Fonte: Autora, 2017.
Gráfico 12: pergunta referente ao conhecimento acerca da frequência de reuniões em associações.

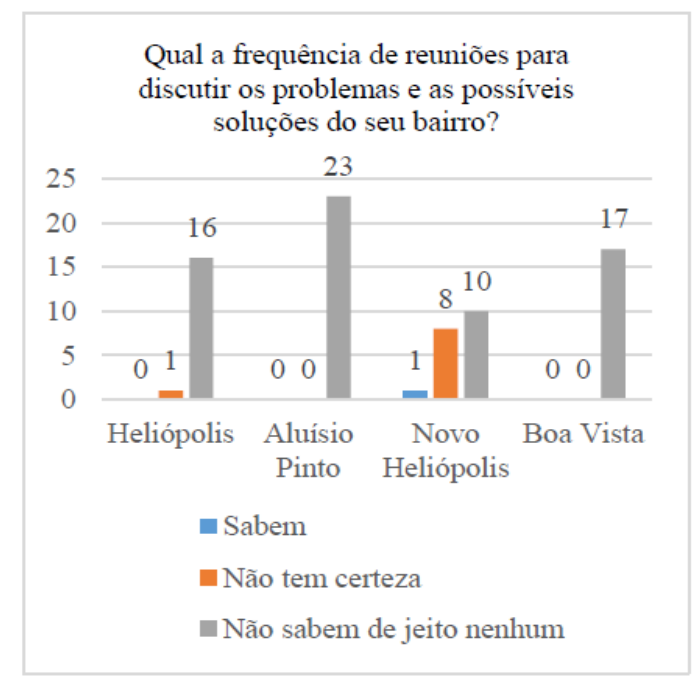

Fonte: Autora, 2017.

Gráfico 14: pergunta referente ao nível de satisfação acerca da segurança em seu bairro.

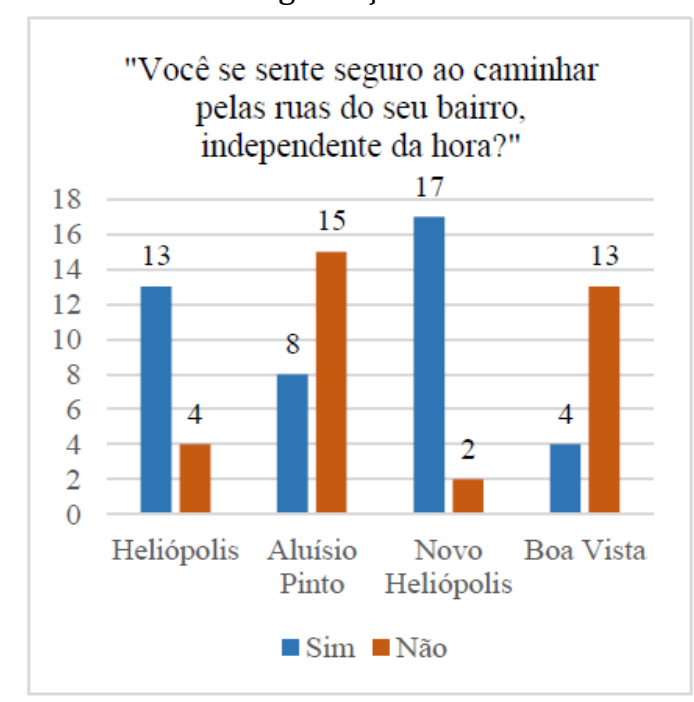

Fonte: Autora, 2017.

A segurança nos bairros foi um ponto de discussão com os entrevistados (Gráficos 13 e 14), mas muitos relataram que há a participação da Polícia Militar e grupos de segurança privada. Isso reflete na questão referente a sensação de caminhar no próprio bairro independente da hora. Muitos entrevistados se sentem seguros, portanto, satisfeitos nos bairros. 
No gráfico 15, percebe-se a satisfação quanto a existência de comércios suficientes para os moradores dos quatro bairros, porém, ao analisar o gráfico 16, observa-se que não são comércio de primeiras necessidades (padaria, farmácia e mercadinho) para todos os moradores do bairro Novo Heliópolis e três do bairro Aluísio Pinto. No segundo, três entrevistados alegaram que estão satisfeitos quanto ao comércio de primeiras necessidades, mas o percurso de suas casas para alguns desses pontos torna-se difícil por ser muito longe e estes serem de muita idade.

Gráfico 15: pergunta referente ao nível de satisfação acerca do comércio em seu bairro.

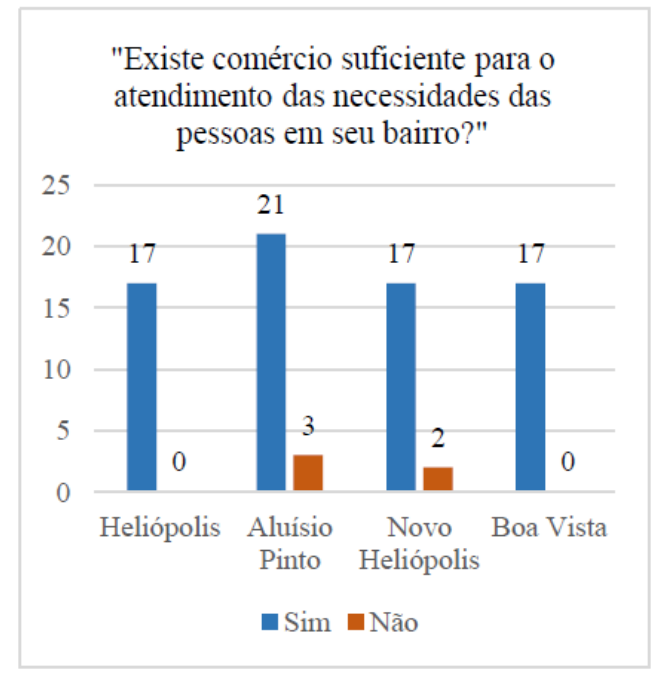

Fonte: Autora, 2017.

Gráfico 17: pergunta referente ao nível de satisfação quanto a existência de templos religiosos no bairro.

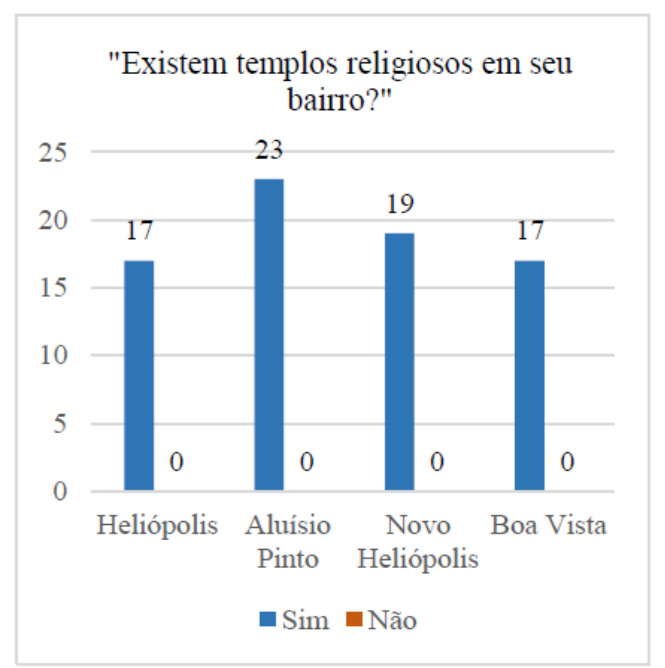

Fonte: Autora, 2017.
Gráfico 16: pergunta referente ao nível de satisfação acerca do comércio em seu bairro.

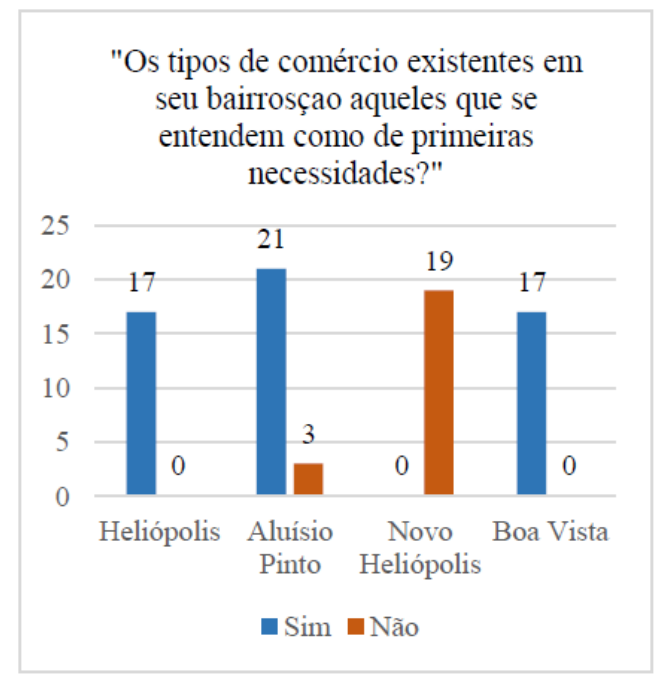

Fonte: Autora, 2017.

Gráfico 18: pergunta referente à opinião sobre a participação dos templos religiosos em seu bairro.

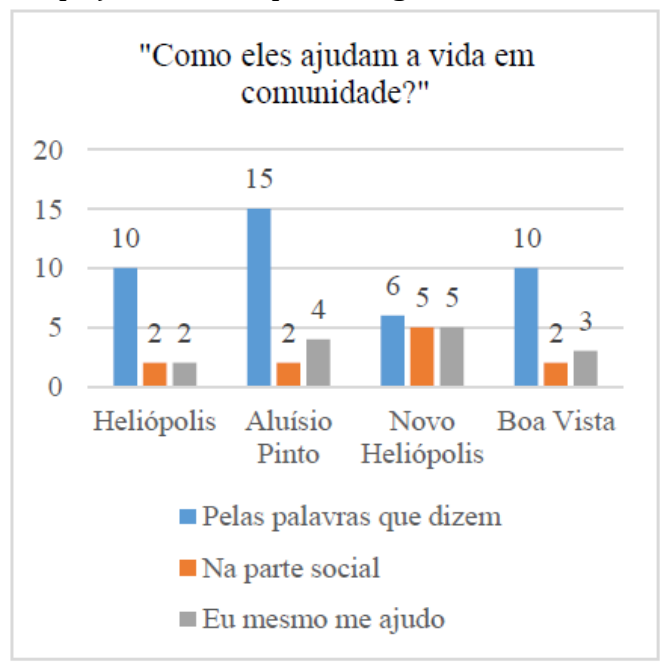

Fonte: Autora, 2017. 
Gráfico 19: pergunta referente ao nível de satisfação quanto a existência de quadras poliesportivas no bairro.

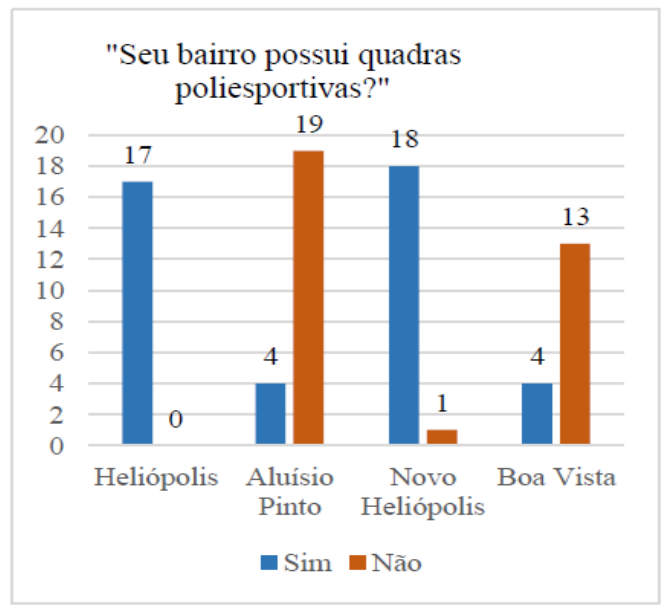

Fonte: Autora, 2017.

Gráfico 21: pergunta referente ao nível de satisfação acerca da infraestrutura básica em seu bairro.

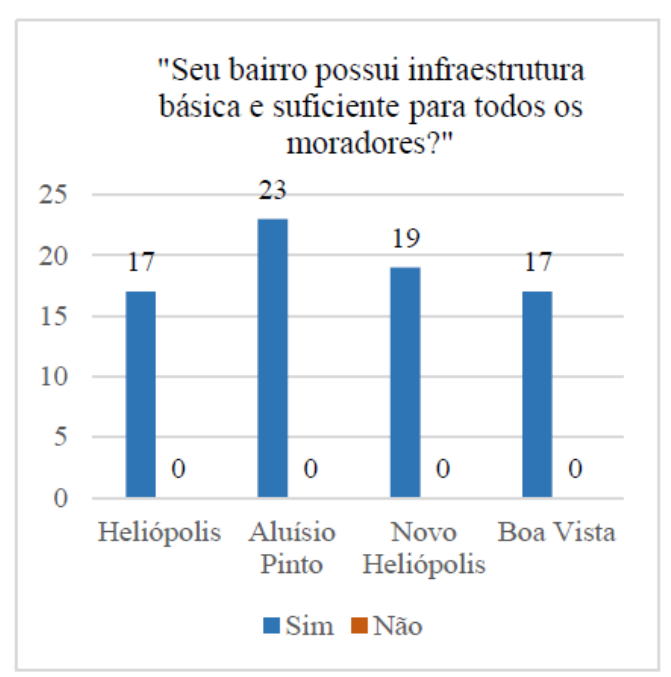

Fonte: Autora, 2017.
Gráfico 20: pergunta referente ao nível de satisfação quanto a disposição de praças em seu bairro.

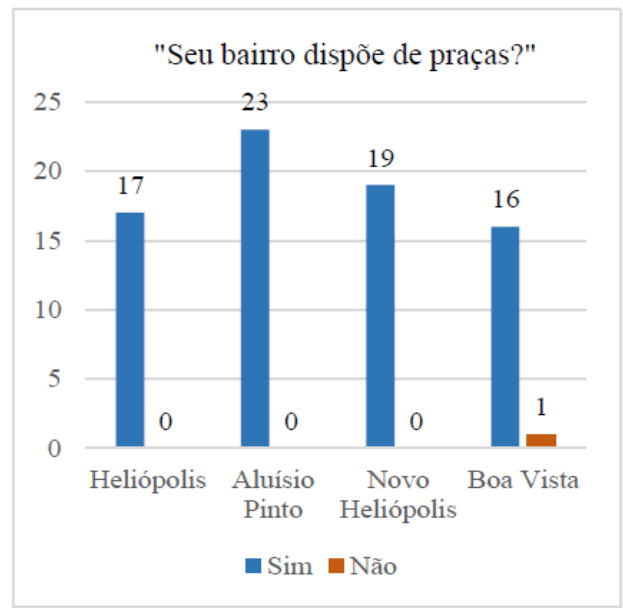

Fonte: Autora, 2017.

Em relação aos templos religiosos (Gráficos 17 e 18), as respostas foram unânimes, todos estavam satisfeitos quanto a existência dos mesmos. Percebe-se que muitos acreditam que esses templos auxiliem a comunidade pelas mensagens que transmitem em suas reuniões. Há ainda a resposta daqueles que acreditam que são importantes pela ação social, através de doações em geral.

0 último ponto da pesquisa relaciona-se a infraestrutura básica e de alguns aspectos dos bairros, como quadras poliesportivas, praças, entre outros (Gráficos 19, 20 e 21), percebe-se respostas satisfatórias, os entrevistados apenas relataram a falta de quadras poliesportivas em seu bairro, aspecto que fica claro na entrevista com os moradores do bairro Aluísio Pinto. 


\section{A ESCOLA E SUA CONTRIBUIÇÃO NA CONSTRUÇÃO COTIDIANA DA CIDADE}

É reconhecida a importância da escola hoje como um espaço rico de oportunidades para o aprendizado de conhecimentos que se leva para a vida toda. Mas, além disso, esta instituição permite ao indivíduo um contato maior com o mundo e com os seus semelhantes, uma relação homem-mundo fundamental para a construção e reconhecimento de sua identidade.

É na escola também que se aprende a ler o mundo e construir a cidadania, pois ao fornecer atividades que possibilitem ao indivíduo interpretar a vida, se permite ao mesmo reconhecer esse mundo e situar-se nele como um cidadão (Callai, 2003, p. 77). A leitura do mundo contribui para a identificação e estudo do território no qual está inserido e relações humanas presentes. É nesse contexto que Callai e Zarth (1988, p. 11) defendem que, a partir da identificação do território, o estudo do município na educação básica se torne imprescindível, pois é o aluno que transforma esse espaço e participa das relações humanas.

A partir desta discussão, a presente pesquisa buscou também verificar o nível de conhecimento de alunos de escolas públicas, visto que estes são os cidadãos que transformarão e participarão da sociedade no futuro, sendo igualmente importante o nível de consciência de todos no momento atual. Salienta-se que entrevistar alunos não fez parte dos objetivos dessa pesquisa, sendo assim, trata-se de um dado a mais para confirmar os propósitos de entender melhor como o cidadão conhece e respeita a legislação urbana e, no caso, o futuro cidadão já que o jovem de hoje deverá ser o adulto de amanhã em sua plena condição de entender o que é uma cidade e poder participar da construção da mesma, junto ao poder público.

Assim, foram selecionadas quatro escolas públicas, sendo uma em cada bairro considerado na pesquisa, onde foram aplicados questionários a oito alunos, entre dez e dezoito anos. As perguntas utilizadas no questionário foram as mesmas utilizadas para os adultos, porém tomando o cuidado de deixá-las no nível de entendimento dos alunos, conforme pode ser observado nos gráficos seguintes.

Com relação ao conhecimento dos alunos quanto às leis que ajudam a prefeitura e os cidadãos construírem a cidade, é possível perceber (Gráfico 22) que a maioria dos entrevistados não possui conhecimento. A minoria que afirma conhecer relata que já ouviu falar de forma superficial através dos meios de comunicação, mas que não sabiam ao certo do que se tratava e que não se interessavam pelo fato de não reconhecer sua importância. É importante ressaltar que no bairro Novo Heliópolis, os alunos que responderam como conhecedores das leis urbanísticas tiveram a oportunidade de participar de uma palestra fora da escola, que citava superficialmente tais leis, o que auxiliou no entendimento da pergunta em questão. 
Gráfico 22: Respostas dos alunos de escolas municipais quanto ao conhecimento das leis que ajudam a prefeitura e os cidadãos construírem a cidade Garanhuns/PE.

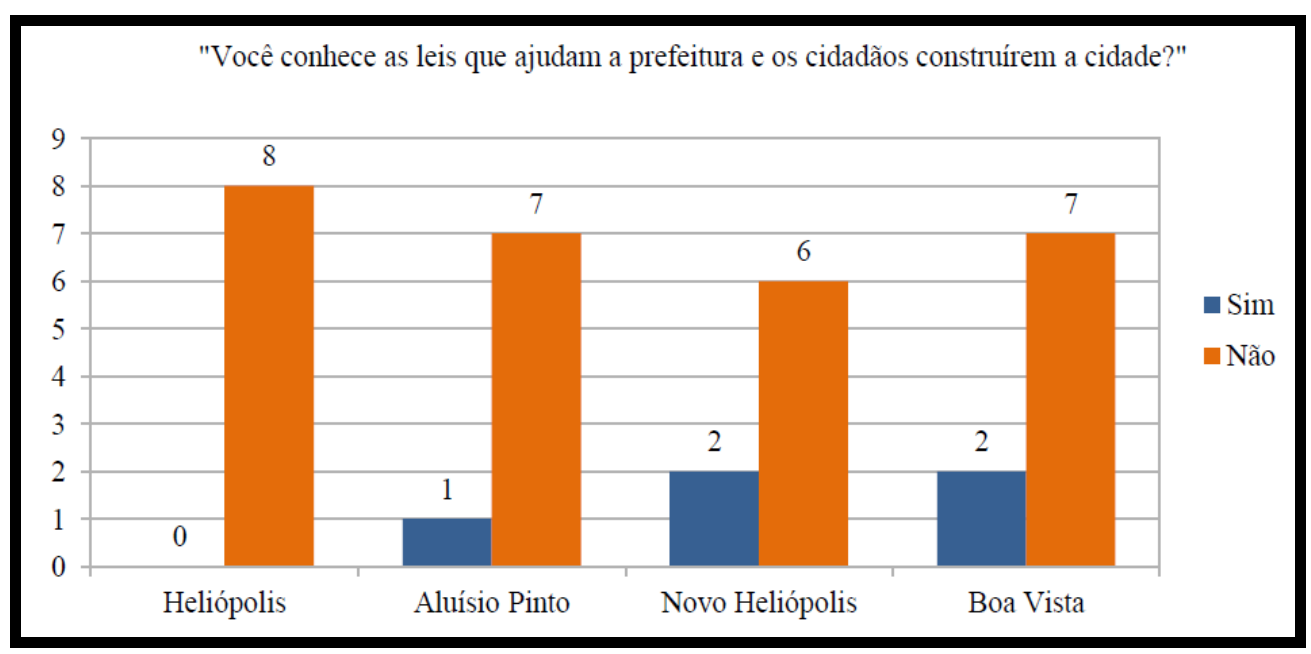

Fonte: Autora (2017).

A estratégia de divisão dos questionários em duas partes também foi utilizada na aplicação aos alunos das escolas municipais selecionadas nos quatro bairros da pesquisa. No gráfico 23, verificase que pouco mais da metade das respostas dos alunos indicam satisfação quanto à qualidade das vias de acessos a sua escola. Em contrapartida, percebe-se que parte considerável não possui a mesma opinião. Observa-se no gráfico 24 que grande parte dos alunos utiliza transporte coletivo (lotação) disponível em seu bairro, pois é o único disponível em três dos quatro bairros.

Gráfico 23: Respostas dos alunos quanto ao nível de satisfação das ruas no percurso de casa para a escola.

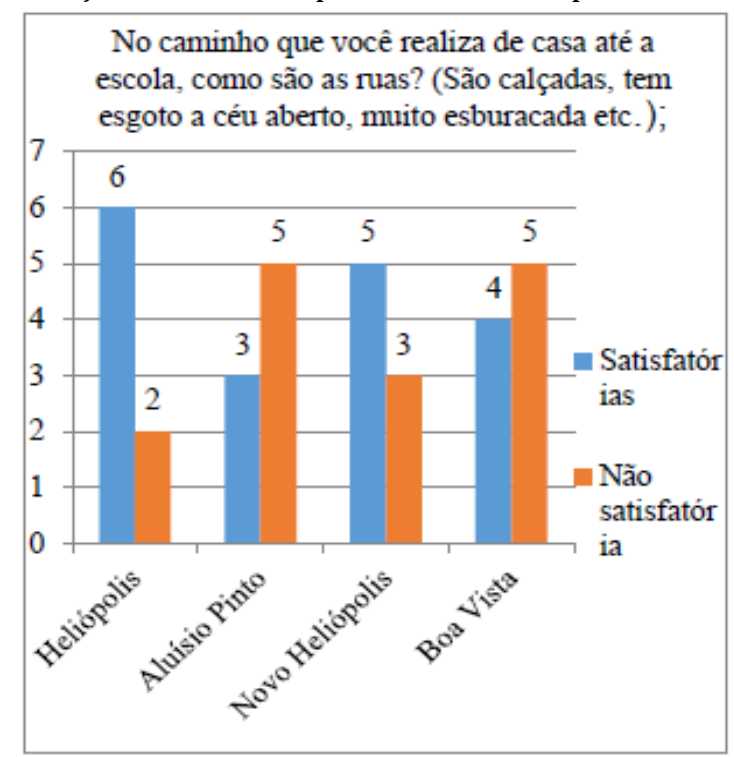

Fonte: Autora, 2017.
Gráfico 24: Repostas dos alunos quanto ao nível de satisfação em relação aos meios de transporte.

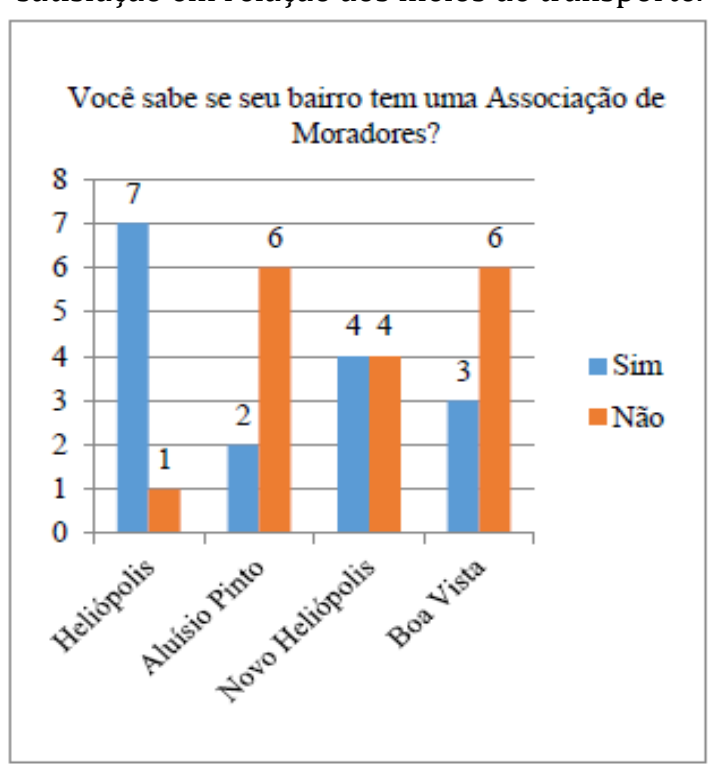

Fonte: Autora, 2017.

Quanto ao nível de satisfação em relação à existência da Associação de Moradores em cada bairro, observa-se que os alunos dos bairros Aluísio Pinto e Boa Vista (Gráfico 25) apresentaram um alto índice de insatisfação em relação aos outros dois bairros. Os alunos que responderam "sim” à BRAGA, M. C. A. A cidade e o cidadão. Verificação e análise do nível de conhecimento das pessoas quanto à legislação... 
pergunta, não sabiam muito bem qual a função destas associações, apenas ouviram poucas vezes por outras pessoas em alguma conversa fora da escola.

Ao questionar os alunos acerca da satisfação quanto à segurança de cada bairro, observa-se no gráfico 26 que o quantitativo de respostas negativas dos alunos das escolas municipais nos quatro bairros foi alto. Em conversas informais com os alunos de algumas dessas escolas que estudam em tempo integral foi relatado que os mesmos se sentem inseguros ao voltar para casa, pois alguns já haviam sido assaltados próximos à escola.

Gráfico 25: Respostas dos alunos quanto ao nível de satisfação em relação à existência de Associação de Moradores.

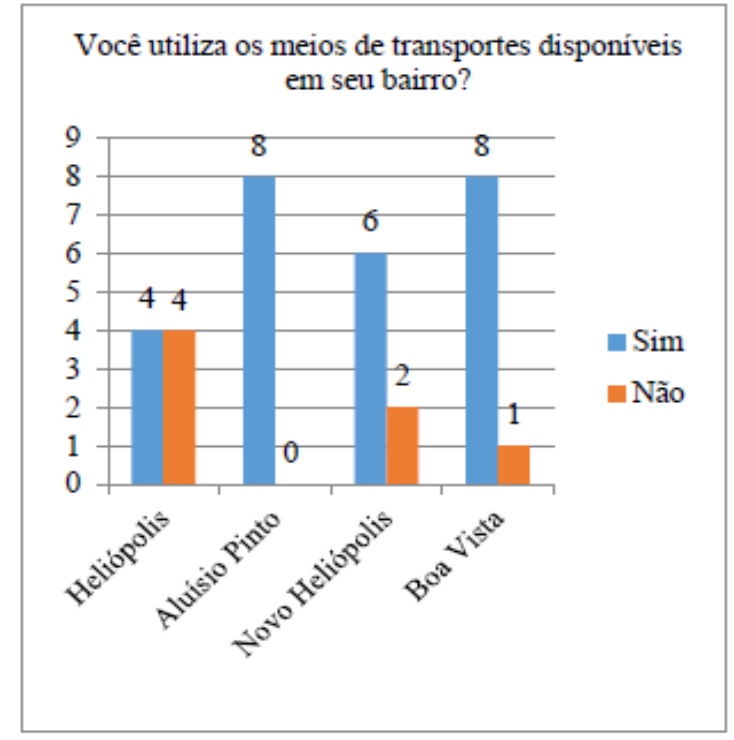

Fonte: Autora, 2017.

Gráfico 27: Respostas dos alunos quanto satisfação em relação ao comércio disponível em cada bairro.

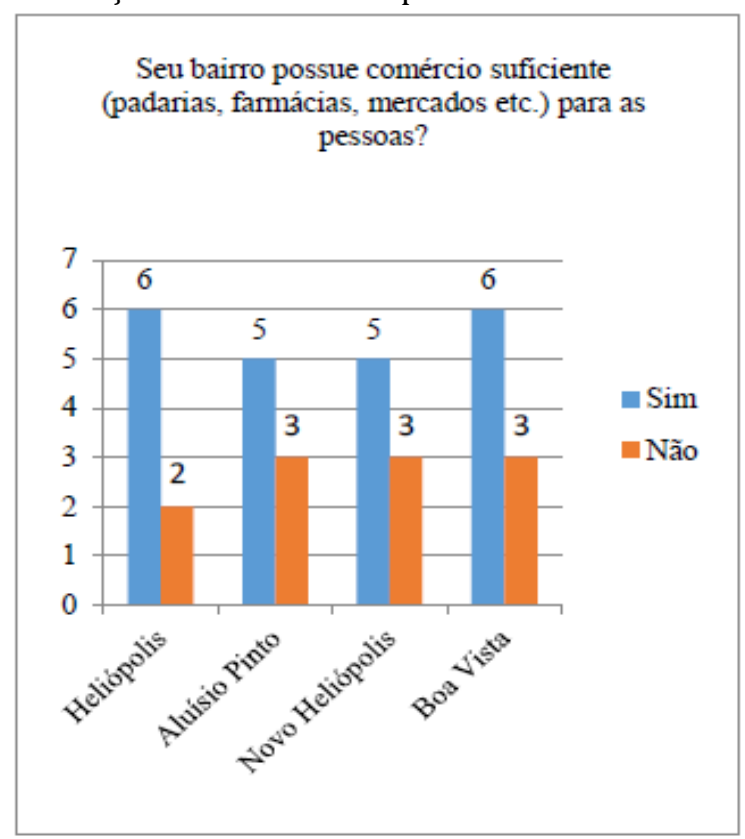

Fonte: Autora, 2017.
Gráfico 26: Respostas dos alunos quanto ao nível de satisfação em relação à segurança.

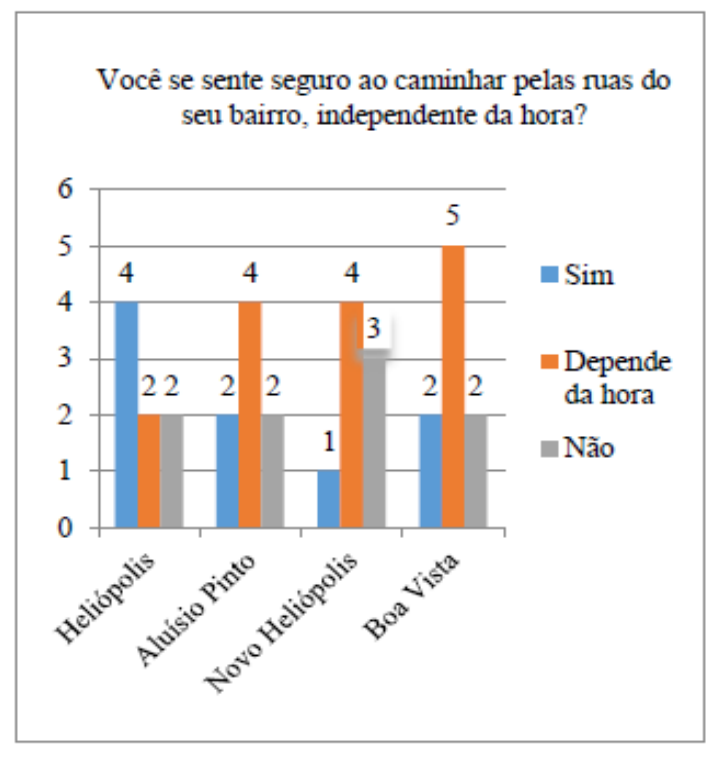

Fonte: Autora, 2017.

Gráfico 28: Respostas dos alunos quanto satisfação em relação ao atendimento das necessidades pelo comércio em cada bairro.

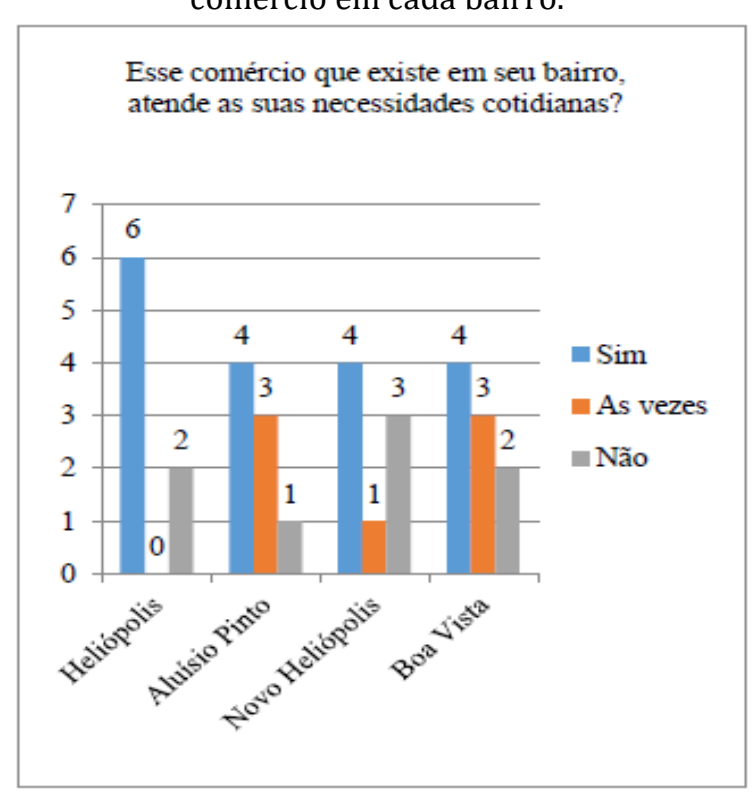

Fonte: Autora, 2017. 
Gráfico 29: Respostas dos alunos quanto ao nível de satisfação em relação à existência de quadras poliesportivas.

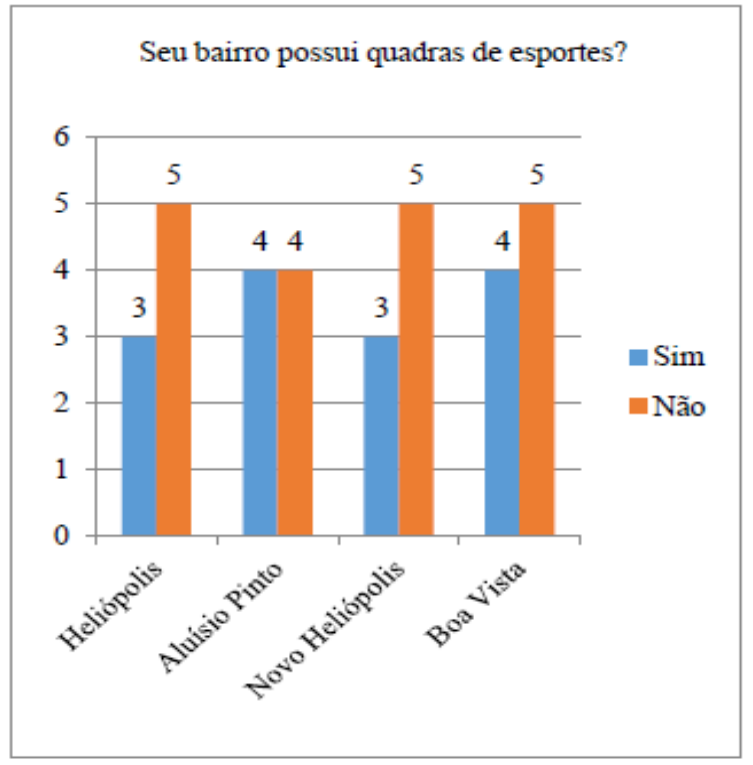

Fonte: Autora, 2017
Gráfico 30: Respostas dos alunos quanto ao nível de satisfação quanto à existência de praças.

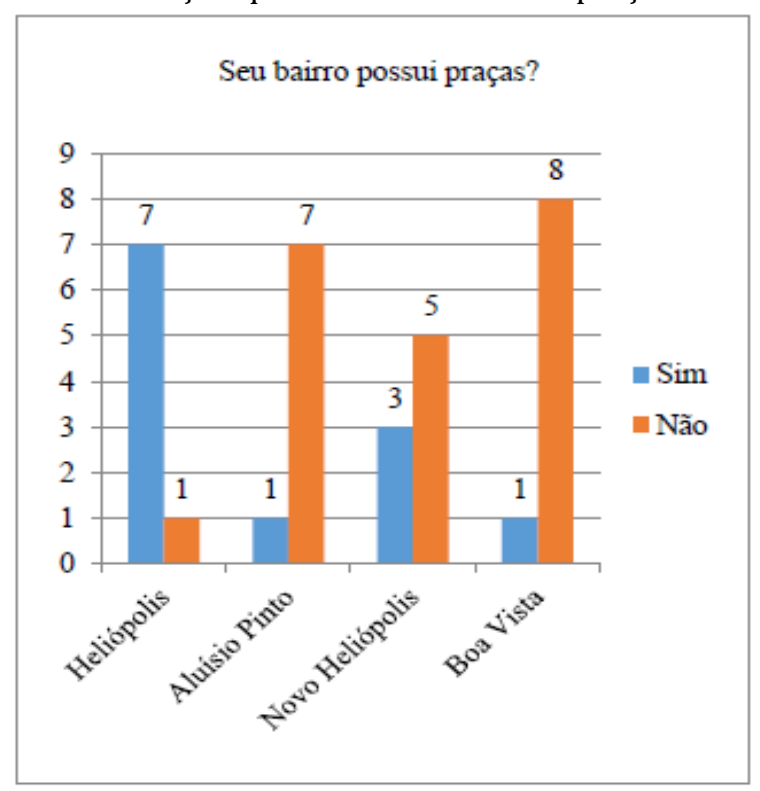

Fonte: Autora, 2017.

Gráfico 31: Respostas dos alunos quanto ao nível de satisfação em relação à infraestrutura básica.

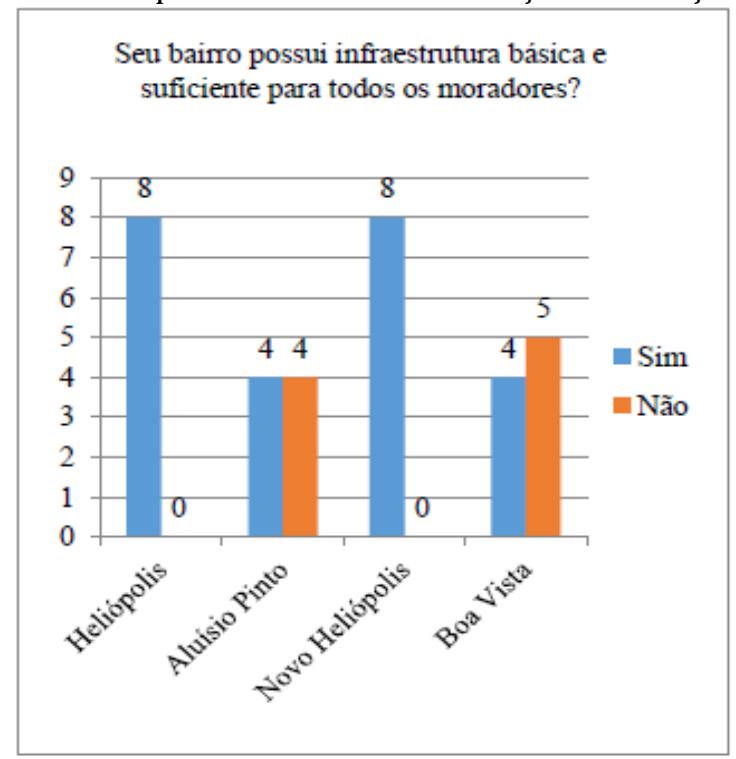

Fonte: Autora, 2017

No gráfico 27, percebe-se que a maioria dos alunos afirma que seus bairros possuem farmácias, padarias, escolas, postos de saúde, mercados, enfim, tudo que considera como comércio suficiente para as pessoas, em contrapartida, ao analisar o gráfico 28 observa-se que apenas os alunos do bairro Heliópolis afirmam que este comércio atende as primeiras necessidades cotidianas das pessoas. Percebe-se também que uma parte dos alunos respondeu com "às vezes", isto porque nestes bairros, como é o caso do bairro Novo Heliópolis, falta estabelecimentos de farmácias, padarias, por exemplo, distribuídas de maneira a atender as necessidades de todos os moradores. 
Nos gráficos 29 e 30, observa-se o alto índice de respostas negativas quanto à questão dos bairros possuírem áreas de lazer e praças. Os alunos relataram que sentem faltam destes pontos, pois gostam de praticar esportes ou até mesmo de se reunir nas praças para interagir com amigos, e para isto precisam se deslocar para longe o que dificulta tais vivências.

0 último ponto do questionário refere-se à infraestrutura dos bairros - isto é, saneamento básico, calçamento, rede de eletricidade, rede de água e esgoto etc. - e percebe-se que as respostas são satisfatórias, apenas enfatizaram mais uma vez sobre a falta das quadras poliesportivas e praças em seus bairros, o que fica claro quando se observa o gráfico 31.

\section{CONCLUSÃO}

A partir dos resultados alcançados neste trabalho, oriundos da aplicação de questionário aos moradores dos bairros Heliópolis, Aluísio Pinto, Novo Heliópolis e Boa Vista, pode-se entender que a legislação urbanística ainda se encontra distante da cotidiana construção da cidade. O que é estabelecido na legislação urbanística tratada na pesquisa (Plano Diretor e as demais leis complementares) é desconhecido pela maior parte da sociedade, incluindo-se os jovens de hoje, considerados como 'futuros' cidadãos, e assim não se atende aos princípios para uma cidade justa e muito menos o alcance dos objetivos, o que implica em um nível de insatisfação ou ainda satisfação que não reflete o sentimento em relação à situação ideal para uma vida confortável. A sociedade que conhece a legislação compreende que precisa exercitar sua cidadania para o bem de todos.

Ao incluir na investigação a busca do conhecimento e sentimento do jovem, futuro cidadão participante da construção da cidade, e como este tem sido trabalhado na escola sobre a questão, confirmou-se que também desconhece a legislação. Mas, mais que isso, conhece pouco sobre o que é ser cidadão, embora perceba que há questões presentes em seu bairro que precisam ser alteradas, para se sentir satisfeito.

Assim, com tal entendimento, identifica-se a escola como sendo o meio ideal para ensinar a importância da cidadania, ou seja, reconhecer direitos e cumprir deveres para, então, transformar a realidade local em um ambiente justo e digno para todos.

\section{REFERÊNCIAS}

BRASIL (2002). Estatuto da Cidade: guia para implementação pelos municípios e cidadãos. Lei n. 10.257, de 10 de julho de 2001, que estabelece diretrizes gerais da política urbana. - 2. Ed. Brasília: Câmara dos Deputados, Coordenação de Publicações.
CALLAI, Helena Copetti; ZARTH, P. A (1998). O estudo do município e o ensino de história $e$ geografia. Ijuf: Livraria UNIJUÍ Editora.

CALLAI, Helena Copetti (2003). O estudo do município ou a Geografia nas séries iniciais. In: CASTROGIOVANNI, Antônio Carlos... [et. al.] Geografia em sala de aula: práticas e reflexões. 
Porto Alegre: Editora da UFRGS/Associação dos Geógrafos Brasileiros.

CONDEPE/FIDEM (2017). Agência Estadual de Planejamento e Pesquisas de Pernambuco. Pernambuco em Mapas. Disponível em: < http://www.condepefidem.pe.gov.br/html/PER NAMBUCO\%20EM\%20MAPAS.pdf>. Acesso em 16 de fev. 2017.

CYMBALISTA, Renato. Conselho de Desenvolvimento Urbano. DICAS Instituto Polis Ideias para ação Municipal, Boletim Instituto Polis, DU No.137, 1999.

GARANHUNS (2008). Plano Diretor Municipal de Garanhuns 2008. Texto original elaborado para a execução e aprovação da Lei Municipal Plano Diretor de Garanhuns, aprovado na Câmara de Vereadores e sancionado pelo prefeito, em 23 de dezembro de 2008. Texto oficial disponível em: <http://198.136.50.100:8080/garanhun_ncA/co nsulta.do?metodo=iniciaAreas\&area123\&contad or $=20291>$. Acesso em 20 de out. de 2016.

IBGE (2016). Conheça Cidades e Estados do Brasil. Disponível em: <http://www.cidades .ibge.gov.br/xtras/perfil.php?lang=\&codmun=26 0600>. Acesso em: 16 de nov. de 2016.

OLIVEIRA, Isabel Cristina Eiras de. Estatuto da Cidade: para compreender... Rio de Janeiro: IBAM/DUMA, 2001. 